\title{
BIOMARKERS ASSOCIATED WITH OBESITY AND OVERWEIGHT IN THE ROMA POPULATION RESIDING IN EASTERN SLOVAKIA
}

\author{
Darina Petrášová1, Izabela Bertková1 ${ }^{1}$ Miroslava Petrášová2, Emília Hijová1, Mária Mareková3 ${ }^{3}$ Ingrid Babinská4, \\ Peter Jarčuška ${ }^{5}$, Daniel Pella ${ }^{5}$, Andrea Madarasová Gecková ${ }^{4,6}$; HepaMeta Team* \\ ${ }^{1}$ Department of Experimental Medicine, Faculty of Medicine, P. J. Šafárik University in Košice, Košice, Slovakia \\ 22nd Department of Paediatrics and Adolescent Medicine, Faculty of Medicine, P. J. Šafárik University in Košice, Košice, Slovakia \\ ${ }^{3}$ Department of Medical and Clinical Biochemistry and LABMED, Faculty of Medicine, P. J. Šafárik University in Košice, Košice, Slovakia \\ ${ }^{4}$ Health Psychology Unit, Department of Public Health, Faculty of Medicine, P. J. Šafárik University in Košice, Košice, Slovakia \\ ${ }^{51}$ st Department of Internal Medicine, Faculty of Medicine, P. J. Šafárik University in Košice, Košice, Slovakia \\ ${ }^{6}$ Olomouc University Social Health Institute, Palacký University in Olomouc, Olomouc, Czech Republic
}

\section{SUMMARY}

Background: Obesity and overweight are major contributors to the global burden of chronic diseases and disability in both majority and minority populations.

Methods: Data from the cross-sectional population-based HepaMeta study conducted in Slovakia in 2011 were used. The sample comprised a total of 452 Roma. Measurements of special bioactive mediators were taken in final groups consisting of 63 male Roma respondents (mean age $=32.59 ; \mathrm{SD}=8.63$ ) and 117 female Roma respondents (mean age $=34.55 ; \mathrm{SD}=8.35$ ). Respondents were divided into three groups: those with normal weight, those with overweight and obese. Values for anthropometric parameters, lipids parameters, C-reactive protein, TNF-a, IL-6, leptin, and adiponectin were determined.

Results: $27.6 \%$ of examined Roma females and $26.9 \%$ of males were overweight. Obesity (BMl $\left.>30.0 \mathrm{~kg} / \mathrm{m}^{2}\right)$ appeared in a higher proportion of males $(28.8 \%)$ compared with female $(26.5 \%)$. Mean levels of total cholesterol, triacylglycerol and LDL-cholesterol were significantly elevated in the overweight and obese subjects compared to normal-weight Roma respondents. The relation was reversed for HDL-C level, with significantly decreased levels in both male and female obese Roma $(p<0.001)$. The concentration of adiponectin was significantly lower in obese subjects of both genders versus non-obese (Roma male $p<0.001$, Roma female $p<0.05$ ). Plasma levels of leptin, IL-6, hs-CRP as well as TNF-a increased in Roma significantly with increasing BMI.

Conclusion: The study is the first one to provide data about selected biomarkers. Results may be useful in predicting obesity and its related diseases in the Roma population from the eastern part of Slovakia.

Key words: Roma population, obesity, overweight, chronic disease

Address for correspondence: D. Petrášová, Department of Experimental Medicine, Faculty of Medicine, P. J. Šafárik University in Košice, Tr. SNP 1, 04011 Košice, Slovakia. E-mail: darina.petrasova@upjs.sk

\section{INTRODUCTION}

Overweight and obesity are defined as abnormal or excessive fat accumulation that presents greater risk for a number of chronic diseases, including diabetes, cardiovascular disease and cancer. The most common measure of obesity is body mass index (BMI), a person's weight (in kilograms) divided by the square of his or her height (in metres, $\mathrm{kg} / \mathrm{m}^{2}$ ). A person with BMI of 30 or more is generally considered to be obese. A person with BMI equal to or more than 25 is considered overweight. According to the World Health Organization (WHO) World Health Statistics 2012 report, one in six adults is obese; one in ten is diabetic; one in three has raised blood pressure, and $65 \%$ of the world's population live in countries where overweight and obesity kill more people than malnutrition (1). WHO Region of the Americas has the high-

\footnotetext{
*HepaMeta Team members are listed in Appendix
}

est obesity rates (26\% of adults), and the lowest occur in WHO South-East Asia Region (3\% obese). In Slovakia, the estimated prevalence of overweight and obesity together (BMI $>25 \mathrm{~kg} / \mathrm{m}^{2}$ ) is $54 \%$ in males and $62.9 \%$ in females, and the prevalence of obesity (BMI $>30 \mathrm{~kg} / \mathrm{m}^{2}$ ) is $12 \%$ in males and $25.3 \%$ in females. Obesity is a fast-growing problem that is reaching epidemic proportions worldwide, as it is associated with increased risk of premature death (2). Different mechanisms linking obesity to cardiovascular disease have been postulated, thus adding on to classical risk factors. Adipose tissue is an active endocrine and paracrine organ that releases a large number of cytokines and bioactive mediators, such as leptin, adiponectin, interleukin-6 (IL-6), and tumour necrosis factor- $\alpha$ (TNF- $\alpha$ ), that influence not only body weight homeostasis but also insulin resistance, diabetes, lipid levels, tension, coagulation, fibrinolysis, inflammation, and atherosclerosis (3). The European Union and WHO emphasise the need for research on the health status of endangered minorities. In the past, the specific attention paid to the socioeconomic and health 
problems of the Roma population were considered to be a violation of the population integrity. Therefore, there is a lack of reliable data on the health status of the Roma population in Slovakia.

The aim of the research was to obtain data on overweight and obesity prevalence in the population living in Roma settlements as well as on bioactive mediators and selected biochemical parameters.

\section{MATERIALS AND METHODS}

Data from the cross-sectional population-based HepaMeta study conducted in Slovakia in 2011 were used. From all Roma who were present in the settlements and received information about the study, 452 (mean age =34.7; SD=9.14; 35.2\% men) chose to participate. However, for measurement of special bioactive mediators, two groups consisting of only 63 men (mean age $=32.59$, $\mathrm{SD}=8.63$ ) and 117 women (mean age $=34.55, \mathrm{SD}=8.35$ ) were selectively created. Respondents were divided into three groups: those with normal weight, those with overweight and obese. Values for anthropometric parameters, lipids parameters, C-reactive protein, TNF- $\alpha$, IL-6, leptin, and adiponectin were determined. The study was approved by the Ethics Committee of the Faculty of Medicine at Šafárik University in Košice. Participation in the study was fully voluntary and anonymous. The methodology is described in detail elsewhere (4).

Results were statistically processed. The student's t-test and chi-square tests were used to determine the significance of differences between groups.

\section{RESULTS}

Among Roma respondents $26.9 \%$ of males and $27.6 \%$ of females were overweight; $28.8 \%$ of males and $26.5 \%$ of females were obese (Fig. 1).

The levels of bioactive mediators and selected biochemical parameters in Roma male respondents are shown in Table 1 and in Roma female respondents in Table 2. Mean levels of TC, TG and LDL-C were significantly higher in overweight and obese examined subjects compared to normal-weight Roma respondents. The relation was reversed for HDL-C level, with significantly lower levels in obese Roma males and females $(\mathrm{p}<0.001)$.

Plasma levels of leptin, IL-6, hs-CRP as well as TNF- $\alpha$ increased in Roma significantly with BMI. Plasma levels of leptin, TNF- $\alpha$

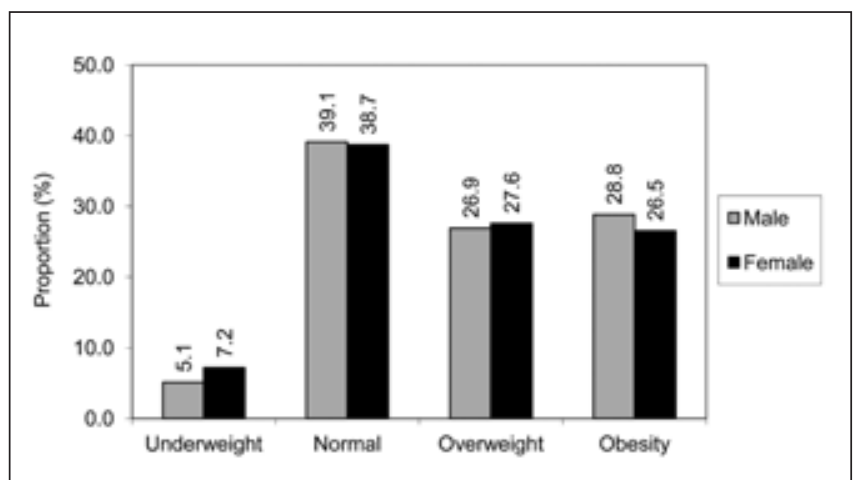

Fig.1. Distribution of Roma respondents in relation to BMI in HepaMeta study. and hs-CRP were significantly higher in obese Roma respondents when compared with non-obese respondents ( $\mathrm{p}<0.001)$. IL-6 levels were significantly higher in obese Roma males in comparison with normal-weight males ( $\mathrm{p}<0.05)$. In obese Roma females mean leptin, TNF- $\alpha$ and IL-6 levels were higher than in obese Roma males. Conversely, mean hs-CRP levels were lower. The concentration of adiponectin was significantly lower in obese of both genders (Roma males $\mathrm{p}<0.001$, Roma females $\mathrm{p}<0.05$ ).

\section{DISCUSSION}

Obesity and overweight are the fifth-leading risk for global deaths and are major contributors to the global burden of chronic diseases and disability. We can compare the results obtained in the project with those obtained by another quantitative questionnaire research of Roma health status, interview was carried out on a representative sample of the Roma population in Slovakia (5). Seven European countries - Spain, Bulgaria, the Czech Republic, Greece, Portugal, Romania and Slovakia - participated in the project "Health and the Roma community, analysis of the situation in Europe", which was financed by the European Union under the "Public Health Programme". The sample population consisted of 700 Roma households. However, due to obstruction in the field, the real sample consisted of 657 respondents (adults and minors) from all regions of Slovakia, with the largest share of representation aged 10-15 years and 45-64 years. Weight problems affect more adult men than women, $48.7 \%$ of men had normal weight, $28.2 \%$ were overweight and $18.7 \%$ were obese. On the other hand, $23.4 \%$ of women were overweight and $17.1 \%$ of women suffered from obesity. Dolinská et al. (6) found in their study that Roma females had higher BMI values compared with majority-population females in all age groups. More than a quarter of Roma women (26.3\%) from the western region of Slovakia were overweight and $14.1 \%$ were obese, while in the eastern region of Slovakia $16.5 \%$ of Roma women were overweight and $6.0 \%$ were obese.

Obesity, in particular excess visceral adiposity, is strongly associated with abnormal cytokine secretion and adverse metabolic risk factors. Adipocytokines secreted from adipose tissue can play a role in the observed link between obesity and its associated morbidities, such as coronary artery disease and insulin resistance $(7,8)$. Therefore, dysregulation of adipocytokines caused by dysfunctional adipocytes (e.g. excess adiposity) could contribute to the pathogenesis of various complications of obesity.

Adiponectin is a protein secreted from adipose tissue which plays an important role in hyperglycemia and inflammatory mechanisms (9). Adiponectin may play a protective role against atherosclerosis and insulin resistance; it is considered to be an important marker signalling the risk of diabetes development in the obese subjects. Moreover, adiponectin may modulate the TNF- $\alpha$ induced inflammatory response, since it has been shown that adiponectin reduces TNF- $\alpha$ secretion of macrophages. This anti-TNF- $\alpha$ effect may partly explain the anti-inflammatory and anti-atherogenic effect of adiponectin (10). In Roma respondents in the present study the serum level of adiponectin correlated inversely with anthropometrical parameters of obese subjects. Consistent with the findings from the present study, lower serum adiponectin levels independent of BMI have been observed in Chinese, Korean, and South Asian women (11) as well as Caucasian men (12). 
Table 1. Anthropometric and biochemical parameters of Roma male respondents

\begin{tabular}{|c|c|c|c|c|c|}
\hline Parameters & $\begin{array}{c}\text { Normal weight } \\
\quad(x \pm S D)\end{array}$ & 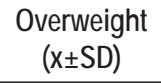 & $\mathrm{p}^{\mathrm{a}}$ & $\begin{array}{l}\text { Obese } \\
(x \pm S D)\end{array}$ & $\mathrm{p}^{\mathrm{b}}$ \\
\hline $\mathrm{N}$ & 18 & 22 & & 23 & \\
\hline Age (y) & $28.70 \pm 8.00$ & $33.97 \pm 9.01$ & & $35.12 \pm 8.88$ & $<0.05$ \\
\hline Weight (kg) & $60.61 \pm 4.71$ & $77.41 \pm 6.46$ & $<0.001$ & $99.26 \pm 9.51$ & $<0.001$ \\
\hline Height (cm) & $170.33 \pm 6.70$ & $167.00 \pm 6.48$ & & $170.57 \pm 4.49$ & \\
\hline $\mathrm{BMI}\left(\mathrm{kg} / \mathrm{m}^{2}\right)$ & $20.88 \pm 0.98$ & $27.74 \pm 1.43$ & $<0.001$ & $34.12 \pm 3.08$ & $<0.001$ \\
\hline Waist circumference (cm) & $78.28 \pm 4.17$ & $92.45 \pm 9.48$ & $<0.001$ & $111.74 \pm 8.91$ & $<0.001$ \\
\hline Hip (cm) & $92.56 \pm 3.93$ & $102.77 \pm 5.23$ & $<0.001$ & $114.40 \pm 6.16$ & $<0.001$ \\
\hline WHR & $0.85 \pm 0.05$ & $0.90 \pm 0.08$ & $<0.05$ & $0.98 \pm 0.06$ & $<0.001$ \\
\hline Total cholesterol (mmol/l) & $4.40 \pm 0.47$ & $4.97 \pm 1.06$ & & $4.86 \pm 1.06$ & \\
\hline Triacylglycerol (mmol/l) & $0.83 \pm 0.29$ & $1.39 \pm 0.58$ & $<0.001$ & $2.63 \pm 2.14$ & $<0.001$ \\
\hline HDL cholesterol (mmol/l) & $1.12 \pm 0.30$ & $1.03 \pm 0.26$ & & $0.79 \pm 0.17$ & $<0.001$ \\
\hline LDL cholesterol (mmol/l) & $2.26 \pm 0.39$ & $2.72 \pm 0.68$ & & $2.51 \pm 0.73$ & \\
\hline hs-CRP (mg/l) & $1.11 \pm 0.93$ & $1.79 \pm 1.43$ & & $4.63 \pm 2.90$ & $<0.001$ \\
\hline TNF alpha (pg/ml) & $8.30 \pm 1.08$ & $8.44 \pm 1.37$ & & $9.52 \pm 2.40$ & $<0.001$ \\
\hline Adiponectin (ng/ml) & $5.20 \pm 2.36$ & $3.30 \pm 1.95$ & $<0.001$ & $2.65 \pm 1.28$ & $<0.001$ \\
\hline Leptin (ng/ml) & $5.60 \pm 3.12$ & $6.24 \pm 3.08$ & & $14.53 \pm 7.84$ & $<0.001$ \\
\hline IL-6 (pg/ml) & $22.56 \pm 1.91$ & $23.03 \pm 2.68$ & & $26.99 \pm 9.31$ & $<0.05$ \\
\hline
\end{tabular}

Table 2. Anthropometric and biochemical parameters of Roma female respondents

\begin{tabular}{|c|c|c|c|c|c|}
\hline Parameters & $\begin{array}{c}\text { Normal weight } \\
(x \pm S D)\end{array}$ & $\begin{array}{l}\text { Overweight } \\
\text { (x士SD) }\end{array}$ & $\mathrm{p}^{\mathrm{a}}$ & $\begin{array}{l}\text { Obese } \\
\text { (x } \pm \text { SD) }\end{array}$ & $p^{b}$ \\
\hline $\mathrm{N}$ & 20 & 62 & & 35 & \\
\hline Age (y) & $31.77 \pm 7.94$ & $35.17 \pm 8.66$ & & $36.70 \pm 8.45$ & $<0.05$ \\
\hline Weight (kg) & $51.73 \pm 2.61$ & $66.07 \pm 7.07$ & $<0.001$ & $81.06 \pm 8.92$ & $<0.001$ \\
\hline Height (cm) & $153.05 \pm 4.71$ & $156.98 \pm 6.97$ & & $153.74 \pm 7.37$ & \\
\hline $\mathrm{BMI}\left(\mathrm{kg} / \mathrm{m}^{2}\right)$ & $22.08 \pm 0.56$ & $26.76 \pm 1.59$ & $<0.001$ & $34.26 \pm 2.48$ & $<0.001$ \\
\hline Waist circumference (cm) & $75.75 \pm 6.07$ & $89.21 \pm 7.64$ & $<0.001$ & $101.57 \pm 10.03$ & $<0.001$ \\
\hline Hip (cm) & $93.30 \pm 5.01$ & $103.18 \pm 6.39$ & $<0.001$ & $115.63 \pm 8.95$ & $<0.001$ \\
\hline WHR & $0.81 \pm 0.06$ & $0.86 \pm 0.05$ & $<0.001$ & $0.88 \pm 0.06$ & $<0.001$ \\
\hline Total cholesterol (mmol/l) & $4.27 \pm 0.62$ & $5.06 \pm 1.05$ & & $4.80 \pm 0.70$ & \\
\hline Triacylglycerol (mmol/l) & $0.83 \pm 0.30$ & $1.20 \pm 0.58$ & $<0.01$ & $1.64 \pm 0.91$ & $<0.001$ \\
\hline HDL cholesterol (mmol/l) & $1.23 \pm 0.22$ & $1.13 \pm 0.25$ & & $0.98 \pm 0.23$ & $<0.001$ \\
\hline LDL cholesterol (mmol/l) & $2.15 \pm 0.48$ & $2.71 \pm 0.73$ & & $2.52 \pm 0.44$ & \\
\hline hs-CRP (mg/l) & $0.89 \pm 0.58$ & $2.16 \pm 1.88$ & $<0.01$ & $4.08 \pm 2.83$ & $<0.001$ \\
\hline TNF alpha (pg/ml) & $17.73 \pm 4.07$ & $18.12 \pm 6.49$ & & $22.48 \pm 6.68$ & $<0.01$ \\
\hline Adiponectin (ng/ml) & $6.05 \pm 1.95$ & $5.43 \pm 2.53$ & & $4.88 \pm 1.93$ & $<0.05$ \\
\hline Leptin (ng/mL) & $7.69 \pm 4.78$ & $15.20 \pm 7.12$ & $<0.001$ & $31.04 \pm 12.74$ & $<0.001$ \\
\hline IL-6 (pg/mL) & $25.07 \pm 2.42$ & $25.46 \pm 2.43$ & & $26.65 \pm 4.73$ & \\
\hline
\end{tabular}

Notes to Tables 1 and 2:

Normal weight group: subjects with BMI of 18.5 to $24.9 \mathrm{~kg} / \mathrm{m}^{2}$

Overweight group: subjects with BMI of $25 \mathrm{~kg}$ to $29.9 \mathrm{~kg} / \mathrm{m}^{2}$

Obese group: subjects with BMl of $30 \mathrm{~kg} / \mathrm{m}^{2}$ or more

$\mathrm{p}^{\mathrm{a}}$ - value for the association between normal weight and overweight, $\mathrm{p}^{\mathrm{b}}$ - value for the association between normal weight and obese

Circulating levels and adipose-tissue mRNA expression of leptin are strongly associated with BMI and correlate with body mass index and waist circumference. Leptin is considered to be the missing link between obesity and diabetes, as it has been proved to regulate blood sugar via its control over appetite and fat storage. Leptin concentrations are predominantly determined by subcutaneous adipose tissue and adiponectin by visceral adipose tissue (10). Recent studies have shown that leptin levels are higher in obese subjects but lower in individuals with normal weight (11, 13). The present study supports these findings, as obese Roma 
had lower leptin levels in comparison with non-obese Roma, and serum leptin levels were much higher in overweight and obese Roma females than in the same categories of Roma males. Although leptin acts mainly at the level of the central nervous system to regulate food intake and energy expenditure, there is a relationship between leptin and the low-grade inflammatory state in obesity, suggesting that leptin could exert peripheral biological effects as a function of its cytokine-like structure (14).

Obesity is associated with a chronic inflammatory response, with altered levels of several circulating factors, such as an increase in the plasma levels of CRP, TNF- $\alpha$, IL- 6 , and with other biological markers of inflammation (15-17). Tumour necrosis factor-alpha is a pro-inflammatory cytokine that exerts numerous effects in adipose tissue, including lipid metabolism and insulin signalling, and which circulating levels are increased with obesity and decreased with weight loss (18). Subcutaneous adipose tissue produces interleukine 6 , which increased secretion is associated with increasing BMI and body fat. One of the main effects of IL-6 is induction of hepatic CRP production, which is now known to be an independent, major risk marker of cardiovascular complications $(19,20)$. In our study, overweight and obese Roma males and females show higher plasma levels of TNF- $\alpha$, IL- 6 and CRP compared with Roma respondents with normal weight. These results are in line with the discovery that low-grade inflammation is a characteristic of the obese state and chronic inflammation in adipose tissue could play a crucial role in obesity-related comorbidities.

In conclusion, the presented results describing the levels of bioactive mediators in Roma respondents represent the first-ever data in the scientific literature on this topic in Slovakia. We report that in Roma with overweight and obesity, adiponectin levels are lower, while leptin, TNF- $\alpha$, IL- 6 , and hs-CRP levels are higher compared to subjects with normal weight. Thus, nutritional status is intimately involved in the regulation of immunity. Overweight and an increase in body mass index level for every individual leads to significant changes in adipokines concentrations, which represents a risk for the development of obesity-related complications. As Raine (22) pointed out, focus on individual behavioural change is insufficient and addressing the "upstream" environmental and social determinants of diet and active life style is important.

\section{Acknowledgement}

This research was partially supported by the Research and Development Support Agency, Contract No. APVV-20-032-11; by the Agency of the Slovak Ministry of Education for the Structural Funds of EU, project CEMIO-ITMS: 26220120058 (30\%), and VEGA 1/0456/11 (40\%). This paper was also partially funded within the framework of the project "Social determinants of health in socially and physically disadvantaged and other groups of population” (CZ.1.07/2.3.00/20.0063) and by Roche Slovensko, s. r. o.

\section{Conflict of Interests}

None declared

\section{APPENDIX}

HepaMeta Team: Peter Jarčuška, Andrea Madarasová Gecková, Mária Mareková, Daniel Pella, Leonard Siegfried, Pavol Jarčuška, Lýdia Pastvová, Ján Fedačko, Jana Kollárová, Peter Kolarčik,
Daniela Bobáková, Zuzana Veselská, Ingrid Babinská, Sylvia Dražilová, Jaroslav Rosenberger, Ivan Schréter, Pavol Kristian, Eduard Veselíny, Martin Janičko, Ladislav Virág, Anna Birková, Marta Kmet’ová, Monika Halánová, Darina Petrášová, Katarína Cáriková, Viera Lovayová, Lucia Merkovská, Lucia Jedličková, Ivana Valková

\section{REFERENCES}

1. World Health Organization. World health statistics 2012. Geneva: WHO; 2012.

2. Adams KF, Schatzkin A, Harris TB, Kipnis V, Mouw T, Ballard-Barbash $\mathrm{R}$, et al. Overweight, obesity, and mortality in a large prospective cohort of persons 50 to 71 years old. N Engl J Med. 2006 Aug 24;355(8):763-78

3. Lau DCW, Dhillon B, Yan H, Szmitko PE, Verma S. Adipokines: molecular links between obesity and atherosclerosis. Am J Physiol Heart Circ Physiol. 2005 May;288(5):H2031-41.

4. Madarasová Gecková A, Jarčuška P, Mareková M, Pella D, Siegfried L, Jarčuška P, et al.; HepaMeta Team. HepaMeta - Prevalence of hepatitis $\mathrm{B} / \mathrm{C}$ and metabolic syndrome in population living in separated and segregated Roma settlements: a methodology for a cross-sectional populationbased study using community-based approach. Cent Eur J Public Health. 2014 Mar;22 Suppl:S6-11.

5. Popper M, Szeghy P, Šarkozy Š. Health and Roma community: analysis of the situation in Slovakia. Bratislava: Partners for Democratic Change Slovakia; 2009. (In Slovak.)

6. Dolinska S, Kudlackova M, Ginter E. The prevalence of female obesity in the world and in the Slovak Gypsy women. Bratisl Lek Listy. 2007;108(45):207-11.

7. Musaad S, Haynes EN. Biomarkers of obesity and subsequent cardiovascular events. Epidemiol Rev. 2007;29:98-114.

8. Berg AH, Scherer PE. Adipose tissue, inflammation, and cardiovascular disease. Circ Res. 2005 May 13;96(9):939-49.

9. Matsuzawa Y, Funahashi T, Kihara S, Shimomura I. Adiponectin and metabolic syndrome. Arterioscler Thromb Vasc Biol. 2004 Jan;24(1):29-33.

10. Bastard JP, Maachi M, Lagathu C, Kim MJ, Caron M, Vidal H, et al. Recent advances in the relationship between obesity, inflammation, and insulin resistance. Eur Cytokine Netw. 2006 Mar;17(1):4-12.

11. Conroy SM, Chai W, Lim U, Franke AA, Cooney RV, Maskarinec G. Leptin, adiponectin, and obesity among Caucasian and Asian women. Mediators Inflamm. 2011;2011:253580. doi: 10.1155/2011/253580.

12. Hansen D, Dendale P, Beelen M, Jonkers RAM, Mullens A, Corluy L, et al. Plasma adipokine and inflammatory marker concentrations are altered in obese, as opposed to non-obese, type 2 diabetes patients. Eur J Appl Physiol. 2010 Jun;109(3):397-404.

13. Suzuki K, Ito Y, Ochiai J, Kusuhara Y, Hashimoto S, Tokudome S, et al.; JACC Study Group. Relationship between obesity and serum markers of oxidative stress and inflammation in Japanese. Asian Pac J Cancer Prev. 2003 Jul-Sep;4(3):259-66.

14. Ahima RS, Flier JS. Leptin. Annu Rev Physiol. 2000;62:413-37.

15. Albert MA, Glynn RJ, Ridker PM. Plasma concentration of C-reactive protein and the calculated Framingham Coronary Heart Disease Risk Score. Circulation. 2003 Jul 15;108(2):161-5.

16. Engström G, Hedblad B, Stavenow L, Lind P, Janzon L, Lindgärde F. Inflammation-sensitive plasma proteins are associated with future weight gain. Diabetes. 2003 Aug;52(8):2097-101.

17. Greenberg AS, Obin MS. Obesity and the role of adipose tissue in inflammation and metabolism. Am J Clin Nutr. 2006 Feb;83(2):461S-465S.

18. Engeli S, Feldpausch M, Gorzelniak K, Hartwig F, Heintze U, Janke J, et al. Association between adiponectin and mediators of inflammation in obese women. Diabetes. 2003 Apr;52(4):942-7.

19. Ridker PM. Clinical application of C-reactive protein for cardiovascular disease detection and prevention. Circulation. 2003 Jan 28;107(3):363-9.

20. Chiu FH, Chuang CH, Li WC, Weng YM, Fann WC, Lo HY, et al. The association of leptin and C-reactive protein with the cardiovascular risk factors and metabolic syndrome score in Taiwanese adults. Cardiovasc Diabetol. 2012 Apr 25;11:40.

21. Clinical guidelines on the identification, evaluation, and treatment of overweight and obesity in adults - the evidence report. National Institutes of Health. Obes Res. 1998 Sep;6 Suppl 2:51S-209S.

22. Raine KD. Obesity epidemics: inevitable outcome of globalization or preventable public health challenge? Int J Public Health. 2012 Feb;57(1):35-6. 